\title{
Kritikus tömeg alatt: a fejlesztési együttműködés lehetőségei a kisebb nagyvárosokban
}

\author{
Below the critical mass: developmental cooperation \\ in minor cities
}

\author{
LUX GÁBOR
}

LUX Gábor: tudományos munkatárs, MTA Közgazdaság- és Regionális Tudományi Kutatóközpont Regionális Kutatások Intézete, Pécs; lux@rkk.hu

KULCSSZAVAK: agglomeráció, városi rezsim, szerkezetváltás, rugalmasság, útfüggőség

ABSZTRAKT: A globális gazdaságban lezajló folyamatok a bővülő agglomerálódás és a nagyvárosok radikális felértékelődése felé mutatnak. A világvárosok hálózata és a hozzájuk kapcsolódó nagyvárosi központok a magas hozzáadott értékủ gazdasági tevékenységek erős koncentrációját valósítják meg, és ezek a térségek a fejlesztéspolitika idealizált esettanulmányaivá is válnak. Ezzel párhuzamosan azonban az elégséges méretgazdasági előnyökkel nem rendelkező, 100-300 ezer lakosú kisebb nagyvárosok a perifériára sodródás veszélyével kénytelenek szembenézni. Mivel ezek a városok és kapcsolatrendszereik fedik le a közép-európai tér jelentős részét, kritikus kérdés, hogy képesek-e alkalmazkodni az uralkodó térfolyamatokhoz, képesek-e a gazdaságukat jó irányba elmozdító fejlesztő együttműködések kialakítására.

Ebben a tanulmányban három kisebb nagyváros (Pécs, Miskolc és Győr) példáján azt vizsgálom, hogy a gazdasági szerkezet, a telephelyi adottságok és az üzleti környezet átalakulása, valamint a hálózatszerveződés milyen kapcsolatban van a helyi-térségi intézményi struktúrákkal, és mennyiben lehetséges az innovatív fejlesztéspolitika kialakítása olyan térségekben, ahol csak gyenge agglomerációs előnyök találhatók. A tanulmány felhívja a figyelmet a kedvező folytonosságot hordozó örökölt tényezők és az emberi erőforrások, a társadalmi tőke jelentőségére, valamint az ezek folyamatos megújítására képes intézményrendszer fontosságára.

A városi kormányzás gyengesége miatt és meghatározó, tőkeerős hazai nagyvállalatok hiányában nem beszélhetünk fejlesztő városi rezsimekről, de a helyi tudás és a stratégiai gondolkodás városi térségekben fellelhető elemeinek egymáshoz illesztésével kialakíthatók a fejlesztési döntések megfogalmazására és képviseletére alkalmas fejlesztési koalíciók, illetve a neokorporativista (osztrák és délnémet mintájú) modellhez közel álló formalizált együttműködési rendszerek.

Gábor LUX: research fellow, Institute for Regional Studies, Centre for Economic and Regional Studies, Hungarian Academy of Sciences, Pécs; lux@rkk.hu

KEYWORDS: agglomeration, urban regime, industrial restructuring, resilience, path dependency

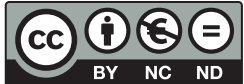


ABSTRACT: Regional studies highlight the relevance of agglomeration economies in the development of city-regions, and the way metropolitan areas have been able to harness their competitive advantages. A system of linked world cities and metropolitan centres have become the main drivers of the global economy with an emphasis on high-value-adding activities. These areas often serve as idealised case studies of urban and regional development, and, as a consequence, concentration has become the underlying logic of a polycentric development policy. As a result, non-metropolitan, minor cities have had to face the consequences of becoming peripheral due to the loss or lack of critical resources, among them the critical mass to muster sufficient agglomerative forces in a competitive field. This, in turn, calls for new adaptive strategies to ensure that urban agglomerations which do not possess a sufficient critical mass can also find a profitable niche which offers developmental opportunities.

In this study, written from the perspective of evolutionary economic geography, the author uses the example of three minor Hungarian cities to highlight different forms of adaptation to the realities of metropolis-driven growth, and the relevance of helpful institutional structures. Based on structured in-depth interviews with key stakeholders in economic development (enterprises, chambers of commerce and development organisations), it is shown that successful development in minor cities hinges on an adaptive restructuring of the local economy, the knowledge-transfer role and economic embeddedness of higher education; and the strength or weakness of urban governance. All examined cities show weaknesses characteristic of post-socialism and/or low urban mass (not enough citizens), but nevertheless serve as examples of how different restructuring strategies have led to widely different degrees of success.

The capacities and traditions of urban governance, as well as strong domestically-owned corporations which characterise North America and Western Europe are missing in post-socialist Central Europe. Owing to their insufficient size and historical underdevelopment, even nationally relevant cities lack the knowledge, resources and power to create fully formed urban regimes, while the business sector is characterised by fragmentation, small firm size and undercapitalisation. Under these circumstances, the needs of development policy would probably be better served by more mosaic-like development coalitions representing the common interests of local stakeholders, or neo-corporative arrangements that resemble the Austrian or South German model of economic governance. This implies the empowerment of chambers of industry and commerce to manage knowledge transfer, generate social and relational capital and represent local business interests, as well as an emphasis on strengthening social dialogue.

Absent strong agglomeration economies, minor cities must make good use of their endogenous resources (particularly human capital), and pay close attention to the development of local-regional innovation systems. Decision makers will need to walk a fine line between the dominant cluster-based development paradigm (emphasising resource concentration and strong specialisation in selected industries), and looking out for the needs of long-term urban resilience (emphasising industrial diversity and adaptability). However, this will prove to be a challenging task due to the limitations of size as well as the scarcity of resources which has become particularly severe in the aftermath of the global financial and economic crisis.

\section{A nagyvárosi agglomerációk előretörése a globális gazdaságban}

A nagyvárosi térségek, agglomerációk térszervezésben betöltött szerepének felértékelődése a modern gazdasági tér szerkezeti átalakulási jelenségeiből, az új térszerveződési formákból következik. A kialakult gazdasági teret egyszerre jellemzi az intenzív verseny és a szorosabb együttműködés, kitüntetett csomópontjai pedig a nagyvárosi térségek, ahol az innovatív, magas értéktermelő ké- 
pességű gazdasági tevékenységek egyre erősebben koncentrálódnak (agglomerálódnak). Az agglomerációk „a társadalmi és gazdasági tevékenységek sűrűsödési pontjai, amelyekben a városmagnak és környékének működése a legteljesebben összefonódott" (Somlyódyné Pfeil 2011, 28.). ${ }^{1}$ A területi szinten kialakuló méretgazdaságosság, az elhelyezkedésből és az urbanizációból, a városi környezetből eredő előnyök együttes hatása a bővülő agglomerálódás felé mutat (Benko 1992; Lengyel, Mozsár 2002).

A logika nem új: telephelyelméletében Alfred Marshall a neoklasszikus közgazdaságtan szemszögéből állított fel kapcsolatot az ipari és a városfejlődés között, és ezt a pozitív gazdasági externáliákhoz kötötte. A hasonló profilú vállalatokat három fö motiváció mozgatja, amikor egymás környezetébe települnek: az iparág számára szükséges, speciális képességeket birtokló munkaerő és az iparág számára szükséges inputok piacának elérhetősége, valamint az információk és a tudás áramlása az egyes vállalatok között (Krugman 1991). Mint Barta $(2002,7$.$) fogalmaz: „A vállalkozások agglomerálódása még több előnnyel, költ-$ ségcsökkenéssel jár számukra, ha együttesen vesznek igénybe működésükhöz szükséges szolgáltatásokat." Számottevő jelentőségűek a szállítási költségek mérséklésének lehetőségéből és a jelentős városi felvevőpiacok elérhetőségéből fakadó együttes előnyök is (Viladecans-Marsal 2002). A közösen élvezett elönyök egyben a vállalatok közötti kapcsolatok sűrűbbé válását eredményezik. Az előnyök kiterjedése azonban nem korlátlan: csak egy adott területi körön belül, a gazdasági koncentrációk környezetében érhetők el; a szállítási és kommunikációs költségek olyan szakadékokat hoznak létre, amelyek a távolság függvényében behatárolják a termelési tényezők megszerzésében élvezett előnyöket (Gordon, McCann 2000). A kiterjedési terület a marshalli értelmezésben a napi ingázási körzet, a christalleri központi helyek elméletében az ellátási funkcióktól függő hierarchikus egység, a növekedési pólusok hagyományos elméletében az iparági vertikum (Egyed 2009), a területi klaszterek fejlesztésében pedig az iparági körzet (Faragó 2006; Harrison 1992; Markusen 1996). Az agglomerálódás behatárolt terének kialakulásával egyensúlyi rendszer alakul ki: a versenyképes gazdaság koncentrált és specializált, városokba települt gócai, valamint a közöttük húzódó, kevésbé koncentrált és másféle karakterü tér kettősségével.

Bár a városrendszerekre mindig jellemző volt a funkciómegosztás és a hierarchia, egyes csomópontok kitüntetett nemzeti vagy nemzetközi szerepe, viszont a 20. század második felében az államhatárok gátszerepének csökkenése, a termelési tényezők áramlása előtti akadályok felszámolása és a gazdaság szerkezeti átalakulása új, szupranacionális integrációs szint és a hozzá tartozó centrumperiféria viszonyok kialakulását eredményezte (Hardi 2010; Ricz 2007). Az újrarendeződésnek egyszerre jellemzője a konvergencia (a feltörekvő gazdaságok és a BRIC-csoport felemelkedése, széles középosztályok megjelenése korábban elmaradott országokban) és a divergencia, a jó helyzetbe került magtérségek (az EU esetében a Pentagon térség vagy Kínában a part menti zóna) felemelkedése és a perifériák stagnálása, esetleg relatív vagy abszolút leszakadása. 
A funkcionális globális hierarchia csúcspontján a világvárosok vagy globális városok állnak (Csomós 2011; Derudder, Taylor, Witlox, Catalano 2003; Erdősi 2003a, 2003b; Faragó 2010; Gál 2010; Sassen 1991, 2006; Taylor, Walker 2001). Ezek a központok a globális áramlások nagy elosztói és koncentrációs pontjai: egyszerre rendelkeznek kapu (gateway) és központ (hub) szerepkörökkel. A posztfordista gazdaság legértékesebb, legnagyobb profittermelő képességü szegmensei, így a pénzügyi és üzleti szolgáltatások, a nagyvállalati központok, a média, a szoftveripar, a design vagy a $\mathrm{K}+\mathrm{F}$ - olyan tevékenységek, amelyek kiemelkedő méretgazdaságossággal rendelkeznek és kontinentális vagy globális piacokat látnak el - rendkívüli módon, globális léptékben sürüsödnek bennük. A tudásintenzív iparban Audretsch (1998) iparági szinten 0,74-es, kimondottan erős korrelációs kapcsolatot tárt fel a K+F-ráfordítások és a kibocsátás (szabadalmak) között. A csúcstechnológiában elért innovatív teljesítmény hatalmas tőkekoncentrációt igényel, és ezért néhány vállalatban, illetve telephelyen összpontosul, méghozzá annál inkább, minél innovatívabb az adott iparág. ${ }^{2}$ Ezzel szemben az életciklusuk érett fázisában levő iparágak tudása erősen kodifikált, könnyen lemásolható, ezért a piacra lépés korlátai is alacsonyabbak. Ez az alacsony költségekkel operáló versenyzők piacra lépését teszi lehetővé (Storper 1992), így a radikális innováció helyett a költségcsökkentésre irányuló folyamatinnováció kerül előtérbe (Caniëls, Romijn 2006; Szalavetz 2003), a vállalatok pedig inkább nagyvárosokon kívüli tereket keresnek telephelyeik számára.

\section{A kisebb nagyvárosok pozíciója és lehetőségei}

Ebben a globális rendszerben - a világgazdasági válság hatására bekövetkező korlátozott visszanemzetiesedés, az állami szerepvállalás erősödése ellenére - a városok a versenyképesség és a gazdasági tér szervezésének fó csomópontjai maradnak. Míg a globális városok és a kiemelt szerepkörü nagyvárosi agglomerációk fejlődése és prosperálása biztosítottnak látszik, a másik oldalon talán a legfontosabb kérdés, hogy milyen pozíciót foglalhatnak el azok a nagyvárosi központok, amelyek nem kitüntetett részei a globális városrendszernek. A kizáró okok sokrétüek: közéjük tartozik a gazdasági elmaradottság, a periferikus földrajzi pozíció, a kedvezőtlen gazdaságszerkezet vagy - legjelentősebb tényezőként - az agglomerációs elönyök kiaknázásához szükséges kritikus tömeg hiánya.

A „kisebb nagyvárosok” (minor cities) problémája úgy fogalmazható meg, hogy képes-e egy városi térség elmozdulni a perifériáról vagy megakadályozni a globális agglomerációs folyamatok eredményezte perifériára sodródást. Míg a regionális tudomány és a városkutatások vizsgálata elsősorban a globális városhierarchia legsikeresebb és legjobban integrált területeit, a globális városokat és az 500 ezres lakosságszámú vagy hasonló nagyságrendủ nagyvárosokat helyezi középpontba, az egy méretkategóriával kisebb, 100-300 ezer fő közötti centrumok lényegesen 
kevesebb figyelmet kaptak - annak ellenére, hogy a városok uralta tér jelentős része az ő vonzáskörzetükbe esik. Sucháček (2010) felveti, hogy ez önmagában a centrum-periféria viszony megjelenése: a nagyobb nagyvárosok a területi fejlődési folyamatok formálói, aktív irányítói, míg a kisebb nagyvárosokban a nagyok erős külső kontrollja érvényesül, ami az alkalmazkodás kérdéseit veti fel számukra. Mint Suvák (2011) figyelmeztet, a „policentrikus” szemléletű fejlesztési minták valójában a funkcionális hierarchiák hordozóiként hatnak a kis- és középvárosokra.

A probléma különösen élesen jelentkezik a posztszocialista Közép- és KeletEurópában, mivel Lengyelország kivételével funkcionálisan gyengék és méretükben (egyben vonzáskörzeteik, agglomerációik kiterjedésében) is alulfejlettek a városhálózat második szintjét képező központok. Szembetűnően illusztrálja a problémákat, hogy az ESPON számításai a fővárosok és jelentős regionális központok, valamint hinterlandjaik közötti különbségek drámai emelkedését mutatták ki 1995 és 2004 között (ESPON 2010), a Csomós (2011) által idézett városrangsorokban pedig szintén a térség lemaradásával szembesülünk. Mindez a centrumtérségek erősödő előnyeire utal: a fejlődés a posztszocialista államokban szigetszerűen megy végbe, az európai és globális integráció előnyeiből egyoldalúan részesülnek a fővárosi agglomerációk.

Az agglomerációs előnyök kvantitatív becslésére számos módszertani megközelítés és empirikus kísérlet született: közülük különleges érdeklődésre tarthat számot Sollé-Ollé és Viladecans-Marsal (2004) vizsgálata Spanyolország, Voith (1998) korábbi munkája az USA, és Koós (2010) elemzése Magyarország városi térségeiről. Mindhárom tanulmány kimutatta a városméret és az agglomerációs előnyök erőssége közötti összefüggést, és rávilágított a kisebb városi térségek hátrányaira a magas hozzáadott értékű szolgáltatások, valamint a tudásintenzív ipar területén. Mindez mérsékelten borúlátó következtetéseket enged levonni Közép-Európa városközpontjaira: a térség nagyvárosai nem rendelkeznek az agglomerációs externáliák teljes kihasználásához elegendő kritikus tömeggel, nem vehetik fel a versenyt az európai magtérségekkel. Az agglomerációs externáliák a kisebb nagyvárosokban is érvényesülnek, de elmaradnak a nagyobbaktól - „papírforma" szerint a fejlettségi különbségek növekedésére lehet számítani a központi régiók és a perifériák között.

A kisebb nagyvárosok elégtelen mérete mellett a városi kormányzás gyengeségei súlyosbítják helyzetüket; komoly visszatartó erőt képviselnek a nyugati mintájú fejlesztő szerepek, a városirezsim-logika befogadásához gyenge, horizontális helyett vertikális kapcsolatrendszerekre épülö önkormányzati rendszer problémái (Nagy 2012; Pálné Kovács 2010, 2011; Somlyódyné Pfeil 2008). Miközben a várostérségekre alapozott fejlesztéspolitika megalapozása intézményi problémákkal küzd, Közép-Európa gazdasági versenyében a versenyképességi tényezők folyamatos átalakulása megy végbe, ami éppen előtérbe helyezésüket, megerősítésüket tenné szükségessé. A befektetésvonzásban a komplex térségi tényezókínálat lép az egyes vonzerők helyére. A munkaerő kínálata mellett emelkedik az annak kialakulását, fenntartását elősegítő intézményrendszer szerepe; 
a városi térségek agglomerációs előnyeiket kínálják fel a befektetők számára. A válsághoz való alkalmazkodásban kritikus jelentőségű a döntéshozók, területi szereplők rugalmassága és alkalmazkodóképessége, ami akkor érvényesíthető hatékonyan, ha a döntéshozatalban és a fejlesztéspolitikában is a mainál jobban érvényesül a szubszidiaritás elve. Ezek a tényezők - bár a nemzeti szintű és szupranacionális folyamatok alapvető befolyást gyakorolnak rájuk - mégis helyi, térségi építkezést tesznek szükségessé: olyan erőforrásokat kell mobilizálni és a fejlesztési rendszerbe illeszteni, amelyek a nemzetinél finomabb skálájú beavatkozást sürgetnek, s a városok aktív, belső erőforrásokra építő és a helyi adottságokat figyelembe vevő fejlesztő szerepét igénylik.

Sürgetőbbé teszi a cselekvést az innováció szerepének átalakulása, egyes innovátorok helyett az innovációs rendszerek elöretörése. Ache (2000) rámutat az átalakulás irányára: a belső erőforrásokat mobilizáló innováció felbomlik, szisztematikussá válik, vagyis nem egyes személyek vagy vállalatok, hanem a környezet elemei uralják az innovációs folyamatot. Az innovációs rendszer az adott tér kontextusában testesül meg; az innovatív impulzusok összefogása és mobilizálása pedig új, kedvező fejlődési (evolúciós) pályákat tesz elérhetővé a térségi gazdaság számára. A környezetet négy alapelem alkotja: a rendszer szereplői; fizikai, nem fizikai és intézményi adottságai; az együttműködést vezérlő interakciós logika; valamint a szereplőkre jellemző tanulási logika. A fejlesztéspolitikai cselekvés mind a négy alapelemen keresztül elősegítheti a rendszer fejlődését.

Így vagy a termelési-szolgáltatási rendszerek hierarchiájába történő, általános versenystratégiákat követő betagozódás, vagy a belső erőforrások, nehezen lemásolható, illetve egyedi térségi előnyök új rendszerbe foglalása kínálja a sikeres alkalmazkodás esélyét. A városhálózaton belüli rugalmas funkciómegosztás (lásd Faragó 2006; Sýkora, Muliček 2009) mérsékelheti az elégtelen kritikus tömegekből adódó versenyhátrányokat, bár ez a kisvárosok részéről jelentős politikai ellenállásba ütközik és diszfunkcionális forráselosztás mellett a különböző területi keretekben szerveződő kormányzati szerveződések folyamatos konfliktusát eredményezi (Hegedüs 2008).

\section{Specializáció és diverzifikáció: Az innovatív fejlesztés alternatívái}

Miként lehet beilleszteni az ideális területi pozíciókon kívül eső, kritikus tömeg alatti városi térségek szempontjait a globális gazdaság hálózataiban helytállni képes, de a hátrányos helyzetű társadalmi csoportokra is tekintettel lévő fejlesztési rendszerbe? Álláspontom szerint a közép-európai kisebb nagyvárosok számára az ideális esetekre kidolgozott és a (nemzeti vagy európai) centrumtérségek érdekeit követő univerzális fejlesztési receptek helyett a belső (endogén) erőforrásokra alapozott, a térségi gazdasági környezet és az emberi erőforrások fejlesztésére 
irányuló fejlesztéspolitika kecsegtet kedvező eredményekkel, ezt a fejlesztéspolitikát pedig területi innovációs rendszerekbe integrálva lehet felépíteni.

A globális folyamatokhoz való, innovációkra alapozó alkalmazkodás két alapvetó fejlödési pálya, a térségi specializáció és a térségi diverzifikáció mentén mehet végbe. Glaeser, Scheinkman és Shleifer nyomán Audretsch (1998) a térségi specializáció előnyeit az iparágon belüli túlcsorduló hatásokban (spilloverekben) látja. Ha egy térségben erős az iparági koncentráció, az azonos területen mủködő vállalatok között könnyűvé válik az információcsere és az új tudás előállítása, mivel tevékenységeik egymáshoz hasonlóak, kommunikációs és tranzakciós költségeik alacsonyak, és mindez a túlcsorduló hatások létrejöttének nagyobb valószínűségéhez vezet. Vagyis erős agglomerációs externáliák (lokalizációs előnyök) jönnek létre. Gordon és McCann (2000) megállapításait idézve a specializáció csökkentheti az agglomerációk versenyképességhez szükséges kritikus tömegének abszolút nagyságrendjét. A kisebb nagyvárosok számára tehát elengedhetetlen valamilyen szintű iparági specializáció, mivel méretükből adódóan nem képesek a metropolisztérségekhez hasonló iparági sokféleséget felvonultatni.

Az összefüggés másik oldalán a térségi diverzifikáció is figyelemre méltó előnyöket kínál. Jacobs és Griliches eredményeit összefoglalva Audretsch (1998) itt az iparágak közötti túlcsorduló hatások (urbanizációs előnyök) előnyeit emeli ki; az eltérő tudástípusok új kombinációi szintén innovatív eredményeket generálhatnak. A városi térségek ideális laboratóriumai az iparágak közötti információcserének, mivel a tudás forrásainak széles skálájával rendelkeznek és a komplementer tudáselemek cserefolyamatok révén a gazdaságban hasznosítható innováció előállítóivá válnak. A kisebb nagyvárosokban csekély lehetőség nyílik az urbanizációs előnyök létrejöttére; Lengyel és Szanyi (2011) ezt Magyarországon empirikus elemzéssel is kimutatta, de hasonló eredményeket találunk Hollandiára (Brouwer, Budil-Nadvornikova, Kleinknecht 1999; van der Panne 2004) és Olaszországra (Paci, Usai 1999) is. Ugyanakkor a diverzifikáció által létrehozott innovatív térségi gazdaság egy másik kulcsfontosságú erénnyel is rendelkezik, ez pedig a külső kihívásokhoz való rugalmas alkalmazkodás képessége (resilience, vö. Tóth 2012). A diverzifikált gazdasággal rendelkező térségekben csekélyebb a szerkezeti válság kialakulásának valószínűsége és nagyobb esély nyílik a pozitív térfolyamatok hozadékainak kiaknázására. A specializáció és a diverzifikáció kapcsán nem tiszta alternatívákról, hanem fejlődési, fejlesztéspolitikai hangsúlyokról, az innováció két megjelenési formájáról van szó; a nagyvárosi térségekben általában mindkét út elemei megfigyelhetők, az egyensúlyi helyzet kialakítása értelmezhető optimális megoldásként (1. ábra).

Ahogy Benneworth (2004), valamint Benneworth és Charles (2005) bemutatja, az innováció nem azonos a csúcstechnológiával, hanem mindazokat a változtatásokat magában foglalja, amelyek hozzájárulnak a gazdasági szereplők, társadalmi csoportok, illetve területi egységek, így a városi térségek hatékonyabb működéséhez. Periferikus helyzetű városi térségekben az innovációs folyamatban a gazdasági szelekció helyett piachelyettesítő logikájú inkubációt 
1. ábra: Specializáció és diverzifikáció az innovatív fejlődésben specialisation and diversification in innovative development

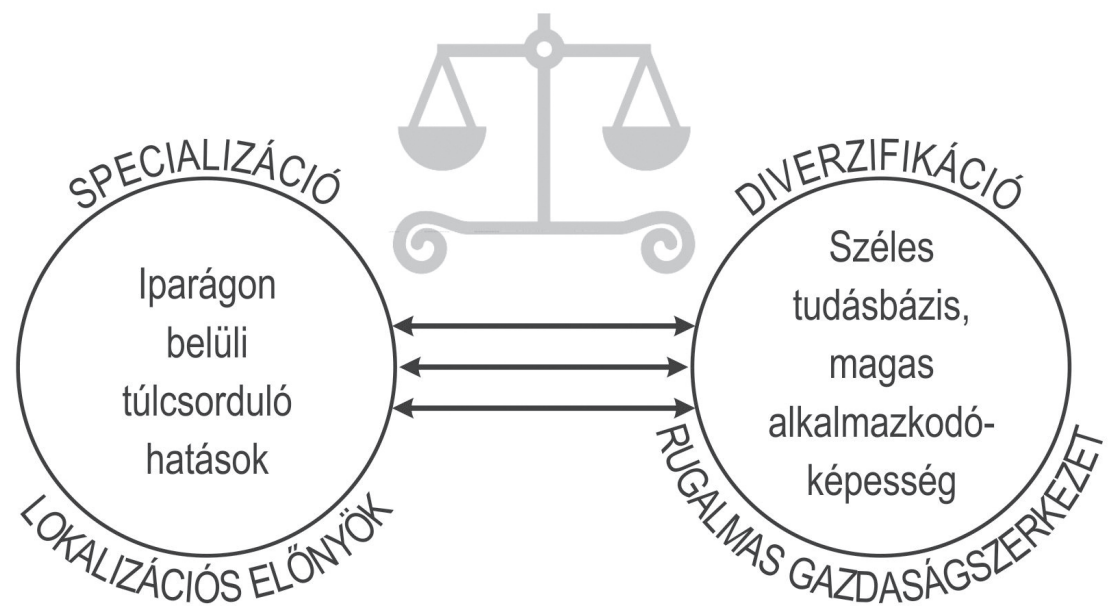

célszerü alkalmazni (Bajmócy 2006). Az innováció formája egyaránt lehet exportképes vagy helyben fogyasztott termék, a termelékenység és értéktermelés növekedésével járó folyamatinnováció vagy a gazdasági és társadalmi hálózatok, esetleg közfeladatok hatékonyságát javító társadalmi, politikai innováció: összefoglalva azok az új minták, amelyek kedvezö evolúciós pályákat nyitnak meg, tárnak fel a városi térségek számára.

\section{A kisebb nagyvárosok problémája három magyar nagyvárosi térségben}

\section{Az esettanulmányok kiválasztása és a kutatási módszerek}

A magyar városhálózat második szintje egyértelmű és régóta ismert problémákkal küzd, amelyekben mind az európai (keleti) periféria általános jegyeit, mind a magyar térfejlődés sajátosságait - különösen a fóváros és a gyenge ellenpólusok kettősségét - tetten érhetjük. A tanulmányban a kisebb nagyvárosok fejlődési útjait, gazdasági központszerepét és az innovatív fejlesztési együttműködés kialakulásának folyamatát három hazai példa, Pécs, Miskolc és Győr esetén keresztül mutatom be. Ez a három város hozzávetőleg azonos méretkategóriát képvisel az európai városhálózatban, 1990 utáni fejlődésük azonban az örökölt tényezők és az új gazdasági környezet miatt merőben eltérő volt. Kiválasztásukat az is indokolja, hogy Magyarország nyolc, 100 ezer fö fölötti népességű városából a KSH 2003-as álláspontja alapján ez a három rendelkezik 
számottevő agglomerációval (közülük egyedül Miskolcé ölti policentrikus városhálózat formáját; Pécs és Győr egyeduralkodó a maga környezetében), továbbá mindhármuk regionális központ.

A fejlődési utak különbségeit elsősorban az iparszerkezet átalakulásának eltérő tendenciáiban érjük tetten. Míg a rendszerváltás idején a közbeszédben és az uralkodó, neoliberális szemléletű gazdasági forrásmunkákban elsősorban a veszteséges nagyipar lebontását tartották a siker zálogának, az átalakulás mintaterületeit nem ott találjuk, ahol a korábbi gazdaság a legnagyobb mértékben megváltozott (vagyis Pécsen, ahol az igen innovatív, szolgáltatásalapú fejlesztési stratégiák vajmi kevés hatást gyakoroltak a „zavartalanul” folytatódó periferizációs folyamatokra), hanem pontosan az iparát legjobban megőrző, azt külföldi tőke bevonásával megújító Győr térségében. Vagyis a termelő hagyományok, térségi működési minták továbbörökítése, az útfüggőség nem csupán egy elavult gazdasági profil konzerválódásához, hanem - ha nem kerül sor a bezárulás (lockin) jelenségére - a korábbi erősségeket megőrző szerves átalakuláshoz is hozzájárulhat (vö. Lux 2009). Ez még a klasszikus ipari válságtérségek modelljéhez legközelebb álló, súlyos depressziót átélt Miskolc esetében is megfigyelhető: a város ipari hagyományai, a kedvező árú munkaerő és az iparhoz kapcsolódó intézményrendszer a külföldi és a hazai tőkére alapuló újraiparosodás számára kedvező lehetőségeket biztosít.

A kiválasztott nagyvárosokban a tanulmányt megalapozó kutatás során összesen 119 részletes strukturált interjút készítettünk; ezekből a továbbiakban azt az ötvenet elemzem, amelyekben gazdasági szereplők voltak az interjúalanyok. A mintában szereplő vállalatokat országos adatbázis alapján, a legjelentősebb foglalkoztatók és legnagyobb adófizetők, valamint a legfontosabb ipari parkok közül választottuk ki; az interjúk között felülreprezentáltak voltak a feldolgozóipari középvállalatok. Az interjúalanyok megoszlása nem volt egyenletes. Pécs 22, Miskolc 20, Győr azonban csak 8 alannyal képviselteti magát; utóbbi városi térségben - bár meghatározó nagyvállalatokat is sikerült elérnünk - kiemelkedően rossz volt a kisebb vállalatok válaszadási hajlandósága. A pontosabb kép érdekében ezért (kissé eltérő kérdéssorral) kiegészítő interjúkat készítettünk térségenként három-három meghatározó fejlesztő szervezet (kereskedelmi és iparkamara, jelentős klaszter, fejlesztéspolitikai szervezet) vezetőjével. A fenti minta nem alkalmas erős kvantitatív eredmények megfogalmazására, a tanulmány táblázataiban szereplő részletes adatok tehát az összesítések kivételével illusztratívak. Az eredmények értékét elsősorban a vállalatvezetők, fejlesztéspolitikai szakemberek részletes kvalitatív válaszai adják, amelyek a helyi fejlesztési problémák pontosabb azonosításában segítettek. A kutatás során a vizsgált nagyvárosi térségeket korábban vizsgáló szakirodalomra is támaszkodtunk; a terjedelmi korlátok miatt azonban ezek ismertetésétől és a szerkezetváltási folyamatok alaposabb bemutatásától itt eltekintek.

A kérdések jelentős része kapcsolódott az adott városi térség telephelyi adottságaihoz és a hozzájuk füződő elvárásokhoz. Külön vizsgáltuk a válaszadók 
telephelyválasztásának okait és a városi központ közelségéből tapasztalt konkrét előnyöket. A kérdésekre kapott válaszok jelentős különbségekre hívták fel a figyelmet. Pécs, Miskolc és Győr eltérő evolúciós pályája az üzleti környezet és az együttműködési kapcsolatok jelentősen eltérő mintáit alakította ki; az eredmények pedig egyben a kisebb nagyvárosok fejlesztési lehetőségeire vonatkozó általános következtetéseket is lehetővé tesznek. Nem találtunk jelentősebb eltéréseket a központi városokban és agglomerációikban letelepült vállalatok között; ez a tényező a várostérségi szemlélet érvényességét látszik igazolni.

\section{Telephelyi előnyök és az üzleti környezet jelentősége}

Az interjúkban elsőként a vállalatok letelepedésének okaira és a központi város nyújtotta előnyökre kérdeztünk rá nyitott kérdések segítségével (1. táblázat). A telephelyválasztás („Kérem, sorolja fel az okokat, amiért a cég itt települt le!”) legnagyobb említési gyakoriságú okát (58\%) mindhárom térségben a helyi kötődés és a történelmi okok jelentették, amely mutatja az útfüggés folyamatos és általában pozitív jelentőségét (ipari hagyományok, tudás és kapcsolatrendszerek továbbadása vagy továbbélése) a gazdasági átalakulásban. Egyes kiemelkedő nagyvállalatok, vállalatcsoportok öröksége megszűnésük vagy átalakulásuk után

1. táblázat: Telepítési tényezők és telephelyi előnyök említési gyakorisága gazdasági szereplők körében (\%)

Location factors and locational advantages mentioned among economic actors (\%)

\begin{tabular}{|c|c|c|c|c|c|c|c|c|}
\hline \multirow[t]{2}{*}{ Ismérvek } & \multicolumn{2}{|c|}{ Pécs } & \multicolumn{2}{|c|}{ Miskolc } & \multicolumn{2}{|c|}{ Györ } & \multicolumn{2}{|c|}{ Összesen } \\
\hline & $\begin{array}{l}\text { telepitési } \\
\text { tényezök }\end{array}$ & $\begin{array}{l}\text { telephely } \\
\text { elönyök }\end{array}$ & $\begin{array}{l}\text { telepitési } \\
\text { tényezők }\end{array}$ & $\begin{array}{l}\text { telephelyi } \\
\text { előnyök }\end{array}$ & $\begin{array}{l}\text { i telepitési } \\
\text { tényezök }\end{array}$ & $\begin{array}{l}\text { telephelyi } \\
\text { elönyök }\end{array}$ & $\begin{array}{l}\text { i telepitési } \\
\text { tényezök }\end{array}$ & $\begin{array}{l}\text { telephelyi } \\
\text { elönyök }\end{array}$ \\
\hline $\begin{array}{l}\text { Helyi kötődés, } \\
\text { történelmi okok }\end{array}$ & 66 & 14 & 53 & 7 & 100 & 83 & 58 & 23 \\
\hline $\begin{array}{l}\text { Közlekedési, logisztikai } \\
\text { helyzet, infrastruktúra }\end{array}$ & 20 & 7 & 42 & 27 & 25 & 50 & 26 & 23 \\
\hline $\begin{array}{l}\text { Támogatások, } \\
\text { kedvezmények }\end{array}$ & - & - & 32 & 7 & - & - & 12 & 3 \\
\hline $\begin{array}{l}\text { Kvantitatív termelési } \\
\text { tényezők (költség- } \\
\text { előny, munkaerő } \\
\text { mennyisége) }\end{array}$ & 20 & 36 & 42 & 13 & 38 & - & 28 & 20 \\
\hline $\begin{array}{l}\text { Kvalitatív termelési } \\
\text { tényezők (képzettség, } \\
\text { egyetem, } \mathrm{K}+\mathrm{F} \text { ) }\end{array}$ & 20 & 36 & 26 & 20 & 38 & 33 & 22 & 29 \\
\hline Városi környezet & 60 & 50 & 42 & 33 & 25 & 83 & 38 & 49 \\
\hline Nincs pozitív hatása & n.é. & 36 & n.é. & 47 & n.é. & - & n.é. & 34 \\
\hline
\end{tabular}

n.é.: nem értelmezheto”. 
is formálja a teret és az üzleti környezetet. A folyamatosság tökéletesen kimutatható és meghatározóan kedvező a győri agglomerációban, részben megfigyelhető a depresszió utáni Miskolc gazdasági környezetében, míg Pécsen a radikális szerkezetváltás és a korábbi periferikus iparágak (bányászat és részlegipar) leépülése után ez a befolyás csekélyebb, elsősorban bizonyos gépipari, elektronikai és könnyüipari tevékenységekben érhető tetten. Más kérdés, hogy a helyi kötődés csak kiváltó ok vagy egyben vonzerő is („Van-e bármiféle pozitív hatása Pécs/Miskolc/Györ városának a vállalkozás/cég tevékenysége szempontjából?"). Győr térségében a válaszadók egyértelműen megfogalmazták a város ipari hagyományainak és működő gazdasági rendszerének jelentőségét (a válaszadók túlnyomó többsége említette őket, és egyetlen interjúalany sem volt, aki szerint a városnak ne lett volna rá pozitív hatása), míg ez a vonzerő Miskolcon és Pécsen sokkal alacsonyabb volt. A helyi kötödés tehát nem esetleges tényezö, hanem a felismert, érzékelhetó agglomerációs elönyök megnyilvánulási formája is - ezek az elönyök ugyanis erős összefüggést mutatnak a versenyelönyt nyújtó termelési tradíciókkal, ipari kultúrával.

A válaszadók negyedének letelepülése kapcsolódott a közlekedési, logisztikai helyzethez és az infrastruktúrához, itt kiemelkedő Miskolc értéke, míg Győr hatékonyan kiaknázza a meglévő nyugati összeköttetéseket és térbeli pozícióját. Pécs környezetében még nem realizálódtak a 2010-ben átadott autópálya-kapcsolat befektetésösztönző hatásai; a reálgazdaság gyengesége miatt az út kihasználatlan.

A támogatások és kedvezmények (elsősorban adókedvezmények, de például a kedvezményes telephelyhez jutási feltételek is) szerepe nem volt kiemelkedő a telephelyi előnyökben, csak a miskolci agglomerációban említették ezeket. Ebben a tekintetben viszonylag csekély a térségspecifikus tényezők szerepe: a vállalkozások közterhei között a nemzeti szinten megállapított adók meghatározóak. Az adóterhelésben egy speciális versenyhátrány, a hatósági gyakorlat szerepe emelhető ki, amelyet a vállalati telephelyváltások kapcsán említek majd.

A termelési tényezők, elsősorban a munkaerő kvantitatív és kvalitatív tényezőit a telephelyválasztás és a város nyújtotta előnyök kapcsán is a válaszadók fele-fele említette. A költségelőnyök elérhetősége, a mérsékelt bérszínvonal elsősorban a miskolci agglomerációban volt a telephelyválasztás jelentős tényezője. A munkaerő-ellátottsághoz kapcsolódó előny azonban nem a puszta olcsóság, hanem a termelésbe vonható munkaerő-tartalékok mennyiségének függvénye is; erősen függ a szakképzés, felsőoktatás színvonalától és a munkaerőpiac más intézményeitől. A munkaerőhiány jelenségét két térségben, de merőben más okból említették a megkérdezettek: Győrben a betelepülő külföldi iparvállalatok lefölözték a rendelkezésre álló szakemberállományt, amelyet a város saját forrásból és belső migrációból sem képes pótolni, míg Pécsen eleve alacsony képzettségi szintről beszélhetünk, és az évek során az ipartelepítéshez szükséges munkaerő-kínálat hiánya a város legfontosabb versenyhátrányává vált. Ez a jelenség a miskolci agglomerációban is megjelenik a tartós depresszió által érintett leszakadó rétegek, így különösen a cigányok katasztrofális foglalkoztatási 
rátáiban. A kvalitatív termelési tényezők (munkaerő képzettsége, egyetemi szolgáltatások, tudástranszfer) a vállalkozások ötödénél szerepeltek a telephelyválasztás okai és harmadánál a városok nyújtotta előnyök között; legnagyobb mértékben a győri vállalatok telephelyválasztásában említették ezeket.

A vizsgált telephelyi adottságok között megjelent a városi környezet szerepe is. Ez egyszerre jelenti a városban elérhető, életminőség jelentette előnyöket, a város intézményellátottságát, valamint az üzleti környezet koncentrációit és ágazati sokszínűségét. Pécsen elsősorban az életminőség elemeit hangsúlyozták; de mint egy válaszadó megfogalmazta, „a városnak egyetlen igazi előnye maradt, a mediterrán sárm, ami a korábbi befektetók vezetöit is elbüvölte". Csupán puha tényezőkre nem lehetséges hatékony versenystratégiát alapozni, de az életminőség jelentős kiegészítő szerepet játszik mind a befektetésvonzásban, mind a magasan kvalifikált munkaerő vonzásában és megtartásában, azaz másodlagos versenyelőnyként viselkedik. Miskolcon és Győrben a város ipari kultúráját, Győrben üzleti környezetét is kiemelték (,Jó lehetőségek nyilnak a gazdasági tevékenységek környezetbe illesztésére. Erősek a versenyképesség minőségi elemei, kialakult egy autóipari beszállitói kör.")

A vállalkozások működésére a szigorú értelemben vett gazdasági tényezők - piacok, inputok, értékesítési és szállítási feltételek stb. - mellett a szélesebb üzleti környezet elemei (az életminőség tényezői, a közintézmények és az üzleti szolgáltatások színvonala) is hatnak. Ezek a lokalitáshoz és a régióhoz erősen kötődő, nem áttelepíthető, de kívülről nézve több potenciális telephelyen elérhető tényezők azok, amelyeket a városok aktív fejlesztő szerepükkel élve leginkább befolyásolni tudnak.

A vállalkozások üzleti környezetének megítélését elsőként a központi város környezetének elemeire rákérdező nyitott kérdéssel vizsgáltuk, majd 0-10 pontig terjedő skálán, ahol a 10 pont jelezte a teljes elégedettséget („Mennyire elégedett ön Pécs/Miskolc/Györ várossal mint a térség gazdasági központjával?", 2. táblázat). A válaszok 6,6-os átlagértékkel a közepesnél valamivel kedvezőbbek, miközben egyértelmű különbségek rajzolódtak ki a kutatásba bevont városok között. Ha a környezeti tényezők értékelését térségenként átlagoljuk, egyfajta „hangulati indexet” kapunk, amely Pécsen mutatja a legborúlátóbb, Győrben pedig a legoptimistább képet. Egyetlen tényező sem volt, amelyet a pécsi agglomeráció gazdasági szereplői a minta átlagánál kedvezőbben ítéltek volna meg, még a város aránylag erősebb kulturális kínálatát, természeti vagy lakókörnyezetét sem. Miskolc esetében a természeti környezet mellett a Miskolci Egyetem kiemelkedően jó pontszáma a kereslethez jól illeszkedő és aktív együttműködési kapcsolatokat kialakító, jelentős tudástranszfert megvalósító intézménynek szól; bár az egyetemi tudás igénybevétele valamivel alacsonyabb volt a megkérdezett vállalatok körében, az együttműködők kedvezően értékelték ezt a kapcsolatot és az egyetem nyújtotta szolgáltatásokat. Győr átlag feletti értékei között kiemelhető Magyarországon egyedülálló ipari telephelykínálata és az egyetem szintén gazdaságbarát profilja. 
2. táblázat: Az üzleti környezet elemeivel való elégedettség gazdasági szereplők körében (0-10 közötti skálán)

Satisfaction with selected factors of the business environment among economic actors (on a 0-10 scale)

\begin{tabular}{lcccc}
\hline \multicolumn{1}{c}{ Elégedettség } & Pécs & Miskolc & Györ & Összesen \\
\hline Az ipari telephely kínálatával & 6,3 & 6,1 & 8,6 & 7,0 \\
A közművesített telekkínálattal & 5,5 & 5,7 & 8,4 & 6,5 \\
A városon belüli közlekedésszervezéssel & 4,6 & 5,6 & 6,4 & 5,5 \\
A helyi adópolitikával & 3,7 & 5,6 & 5,4 & 4,9 \\
Az üzleti szolgáltatásokkal & 6,2 & 6,5 & 7,1 & 6,6 \\
Az egyetem nyújtotta szolgáltatásokkal & 5,3 & 8,1 & 8,6 & 7,3 \\
A természeti környezettel & 7,3 & 8,1 & 7,8 & 7,7 \\
A lakókörnyezettel & 6,8 & 6,4 & 8,3 & 7,2 \\
A szakképzést nyújtó intézmények színvonalával & 4,2 & 6,5 & 7,8 & 6,2 \\
A lakáspolitikával (bérlakásállományával, lakhatási & 3,8 & 5,2 & 6,8 & 5,3 \\
$\quad$ támogatási rendszerével) & & & & \\
A sportolási és rekreációs lehetőségekkel & 5,1 & 7,5 & 8,4 & 7,0 \\
A kulturális kínálattal & 7,4 & 7,6 & 8,4 & 7,8 \\
Az egészségügyi ellátással & 5,6 & 7,0 & 6,5 & 6,4 \\
A közoktatási színvonallal & 5,5 & 6,9 & 7,7 & 6,7 \\
A közlekedési kapcsolatokkal & 5,9 & 7,3 & 6,9 & 6,7 \\
\hline Átlag & 5,5 & 6,7 & 7,5 & 6,6 \\
\hline
\end{tabular}

A vállalkozások által igényelt üzleti és közszolgáltatások esetén nyitott kérdést alkalmaztunk, a helyben el nem érhető szolgáltatások azonosítását kértük az interjúalanyoktól (,Van-e olyan hiányzó üzleti szolgáltatás/közszolgáltatás, amelyet nem tud sem helyben, sem Pécsen/Miskolcon/Györben igénybe venni, de szüksége lenne rá és jelenleg máshol veszi igénybe?”). A válaszadók 57\%-a minden, számára szükséges üzleti, 87\%-uk minden szükséges közszolgáltatást el tudott érni telephelyén vagy az agglomeráció központjában. A hiányzó üzleti szolgáltatások között a legtöbben specifikus gazdasági szolgáltatásokat hiányoltak. Nem feltétlenül a szolgáltatások abszolút hiánya, hanem minőségük, különösen a nemzetközi jelenléthez szükséges szolgáltatások helyi elérhetetlensége jelentett problémákat a vállalkozásoknak, ezek a tevékenységek ugyanis nagyon erös fơvárosi koncentrációt mutatnak, csak korlátozottan jelentek meg a vizsgált városkategóriában. A közszolgáltatások körében a vállalatokat segitő egyablakos ügyintézés és vállalkozóbarát hozzáállás hiányzott a válaszadók egy része számára, de túlnyomó többségük elégedett volt az elérhető közszolgáltatások palettájával és minőségével. Más kérdések kapcsán azonban többen súlyos problémaként azonosították a hatósági gyakorlat elemeit: a vállalkozások, különösen a kis- és középvállalkozások működési feltételeit rontó magas adóterhelés és bürokratikus akadályok mellett az állandó, büntetési kvóták behajtására törekvő és a vidéki térségeket a fövároshoz mérten jóval súlyosabban érintő hatósági ellenőrzéseket emelték ki.

Az üzleti környezettel való elégedettség jelentős indikátora, hogy a letelepült vállalatok a jövőben is helyben képzelik-e el a müködésüket vagy adott fel- 
tételek mellett a telephelyváltás mellett döntenének. A telephelyváltási szándékokat, a döntés indoklását és az előnyösebbnek vélt új telephelyet nyitott kérdéssel vizsgáltuk (,Áthelyezné-e a cég székhelyét más településre, ha módja lenne rá? Ha igen, miért és hová?"). A kérdésfeltevés nem mérlegelte a döntés realitását, csak a szándékot vette figyelembe; így a válaszadók 31\%-a döntött volna új telephely mellett, méghozzá meghatározóan a telephely érzékelt abszolút vagy relatív hátrányai, valamint a rossz adózási feltételek miatt. A legmagasabb áttelepülési hajlandóság Pécsen jelentkezett, és ebben kulcsszerepet játszanak az adózással, hatósági viselkedéssel kapcsolatos problémák. Figyelmeztetést kell jelentsenek azok a válaszok is, amelyek szerint ha a letelepülésüket megalapozó befektetői döntésre most kerülne sor, nem biztos, hogy Pécsre esne a választás, továbbá azok a vélemények, amelyek a város markáns gazdasági profilját és az önkormányzat vállalkozóbarát magatartását hiányolták. A vállalatok telephelyváltási motivációiban a terjeszkedés igénye is tetten érhető: a helyi közegből kinőtt, nemzetközi piacokra dolgozó kis- és középvállalkozások közül többen a fővárosban, a nyugati határ közelében vagy Nyugat-Európában képzelik el jövőjüket, és ez a szándék különösen az innovatív ágazatokra volt jellemző.

\section{Hálózatszerveződés és fejlesztési együttmüködés}

A gazdasági hálózatok szerveződését több kvalitatív kérdéssel és korábbi kutatási eredmények felhasználásával vizsgáltuk, de egy súlyponti területet, a vállalkozások területi beágyazottságát külön kérdéssel érintettük: arra kértük a gazdasági szereplőket, hogy sorolják fel legfontosabb együttműködési kapcsolataikat és röviden jellemezzék ezek tartalmát. A legjelentősebb kapcsolatokat természetesen a gazdasági szereplők jelentették (75\%); kisebb eltérésekkel mindhárom kutatásba vont agglomerációban hasonló súllyal szerepeltek a partnervállalkozások, beszállítói és beszerző kapcsolatok. Szintén gyakorlatilag azonos az érdekképviseletet, szakmai kapcsolatokat és információkat biztosító szakmai szervezetekkel kialakított együttműködés jelentősége (43\%). Ahol jelentős különbségek tapasztalhatók, az a gazdasági szférának a fejlesztő szervezetekkel és az innovációs rendszer szereplőivel kiépített kapcsolatrendszere. A pécsi agglomerációban sokkal alacsonyabb volt a terület- és gazdaságfejlesztési szervezetekkel kialakult kapcsolatok előfordulási gyakorisága (a válaszadók ötöde), mint a másik két városi térségben (a válaszadók több mint fele), és nem alakultak ki erős kapcsolatok az egyetemekkel, főiskolákkal, különösen a munkaerő megszerzésén túlmenő kérdésekben. Vagyis nem csupán a minőségi telephelyi adottságok, hanem az azok hosszabb távú javítására alkalmas fejlesztő és innovációs rendszer állapota is lemaradást mutat.

A helyi tudás hasznosításának fokát van den Berg, Braun és van Winden (2001) hierarchikus kategóriái alapján értékelhetjük (2. ábra). Az egyetemek esetében a puszta munkaerő-kínálaton túllépő, a kihelyezett felsőfokú szakképzéstől 
2. ábra: Stratégiai együttműködési kapcsolatok a felsőoktatásban és a kutatás-fejlesztésben Strategic cooperation linkages in higher education and $R \& D$

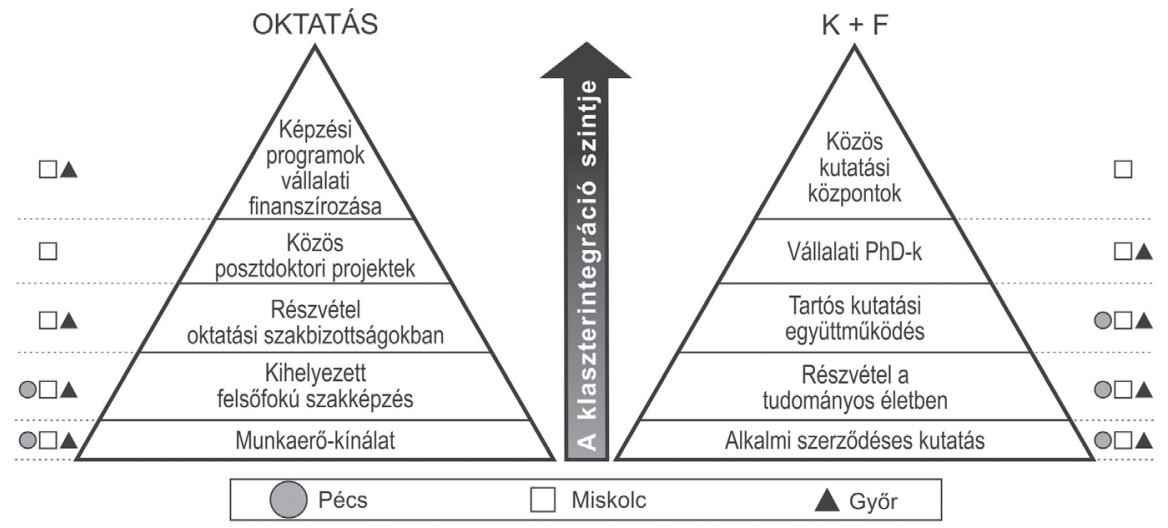

Forrás: van den Berg, Braun, van Winden (2001) alapján.

a vállalati finanszírozású képzési programokig terjedő együttműködési formákról, a kutatás-fejlesztés esetében pedig az alkalmi szerződéses megbízásoktól a tartós együttműködésekig, vállalati PhD-helyekig és közös irányítású, illetve finanszírozású kutatási központokig terjedő együttműködési skáláról beszélhetünk. Erre a kérdésre számos hazai munka is felhívta a figyelmet (a közelmúltban pl. Barta, Csizmadia, Deák, Dőry, Kiss, Lengyel 2011; Csizmadia, Grosz 2011).

Az együttmúködés eltérőek a vizsgált városi agglomerációkban: a Pécsi Tudományegyetemen megjelentek és a klaszterszerveződés alapjaivá váltak az innovatív iparágak kisméretủ spinoffcégei, részvételükkel tartós kutatási együttmüködések alakultak ki: a K+F terén az egyetem akkor is fontos erőt képvisel, ha az eredmények termékesítése még korai fázisban jár. Nem intézményesült azonban az oktatás és a vállalati szféra kapcsolata, s különösen a feldolgozóipar maradt távol az egyetemi szférától - részben az egyetemi kínálat és a vállalati kereslet eltérése miatt. A területi fejlődésben az egyetem kulturális szerepe így ma meghaladja a tudományosat és a gazdaságit is - miközben sokan (Erdős, Varga 2010; Gál 2006; Horeczki 2011; Hrubi 2009; Póla 2009; Szerb 2009) felhívták már a figyelmet az egyetemi tudásra alapozott innovatív gazdaságfejlesztés és az azt támogató intézményi környezet jelentőségére. Az elmúlt évtizedben Rechnitzer (2005) még kedvező véleményt fogalmazott meg a város innovációs potenciáljáról, de ez a lehetőség kiaknázatlan maradt; sőt, a forráselvonásokra reagáló védekező egyetemi stratégia csak további visszaszorulást vetít elöre.

A Miskolci Egyetemen és a hozzá kapcsolódó kutatóintézetekben a szűkebb tudásbázis dacára széles spektrumú és kiépültebb kooperáció valósult meg: az együttműködés elérte az oktatás legmagasabb szintjeit (Robert Bosch Mechatronikai Tanszék, BorsodChem-Wanhua Kína Központ), és jelentős eredmények születtek az egyetemi innovációk vállalati hasznosításában. Erre kínálnak pél- 
dát az informatika és a környezetipar klaszterei, ahol az inkubáció, utóbbinál pedig a szervezett technológia- majd termékfejlesztés is megvalósult. Ez egy olyan, valóban müködő innovációs rendszert bizonyít, amely képes hasznosítani a térségben létrehozott tudást, és ehhez a szükséges tőkét és szervezeti támogatást is biztosítja.

Győrben hasonló, valamivel kevésbé előrehaladott ipari együttmüködések öltenek testet - 2012-ben nyitották meg az Audi Hungaria Járműipari Tanszékcsoportból létrehozott egyetemi intézetet. A nagyvállalatok mellett a városba települt feldolgozóipar kisebb képviselői is részt vesznek a képzési rendszer alakításában; a Professio Fémipari és Szakképzési Klaszter például a kimerülő munkaerő-tartalékok regenerációját tüzte ki célként. Az utánpótlást egyre gyakrabban ösztönzik vállalati tanulmányi szerződésekkel és ösztöndíjakkal. A $\mathrm{K}+\mathrm{F}$-együttműködés legmagasabb szintjei még nem épültek ki a város környezetében (az Audi K+F-egysége vállalaton belül működik), de az alacsonyabb hierarchiaszinteken erősödő intézményesülés zajlik, tartós kutatási kapcsolatok öltenek formát.

A kutatás a feltett kérdéseken túl is fontos tanulságokkal szolgált, különösen a fejlesztési együttműködés formáinak azonosításában. Egyik tanulmányozott kisebb nagyvárosban sem találtunk városirezsim-formát öltő fejlesztési együttműködést, bár az önkormányzatok működésében megtalálhatók a fenntartó (a városi szolgáltatások zökkenőmentes ellátására és közintézmények üzemeltetésére koncentráló) városi rezsimek egyes jegyei. Az önkormányzatok tervezési gyakorlatából rendre hiányoznak a hosszabb távú, koncepcionális szempontok (Suvák 2012), a gyenge gazdasági szervezőerejü városok az egyre intenzívebb városi dimenziójú európai fejlesztési modell befogadására is képtelenek, térszervező aktivitásukat nagyban befolyásolja a kormányzati rendszer centralizációs logikája (Somlyódyné Pfeil 2012). Mint Pálné Kovács Ilona (2012) kimutatja, nem működnek tartós fejlesztési koalíciók, az esetlegessé váló együttműködés pedig inkább a kormányzat és a gazdaság egymástól izolált müködésének vagy a versengő, egyéni érdekkijárásra épülő kliens-patrónus kapcsolatok kialakulásának kedvez.

Ugyanakkor a gazdasági szereplókkel és fejlesztő szervezetekkel készitett interjúk arra engednek következtetni, hogy a gazdasági szférában jelentős tudás halmozódott fel, és a szenior vállalatvezetők, tervezők részéról, valamint a kereskedelmi és iparkamarák szervezeteiben mind az igény, mind a képesség megvan a stratégiai cselekvésre. Ez az együttműködés elsősorban alulról építkező tevékenységekben nyilvánul meg, részben közös vállalati cselekvésben és érdekképviseletben (amely a müködő klaszterszervezetekben is megfigyelhető). Szintén gazdaságszervező, integráló erőként lépnek fel a sikeres ipari parkok, amelyek a vagyonkezelés vagy ingatlanüzlet szintjén túllépve tudatos specializációra vagy erős támogató funkciók kialakítására törekszenek (például a Sajóbábonyi Vegyipari Park és a Győri Ipari Park). A fejlesztő együttműködés potenciális gazdasági szereplői és (általában) lehetséges irányai is megvannak, de müködési feltételeiket még ki kell alakítani. 


\section{Az innovációorientált fejlesztési együttműködés intézményi keretei}

Ahogyan a vizsgált esetek is mutatják, a kritikus tömegek hiányával és intézményi gyengeségekkel küzdő városi térségek egyik legjelentősebb problémája a piacvezérelt, erősen útfüggő fejlődési pályák döntő szerepe a gazdasági fejlődésben. Ez viszonylag kedvező lehet ott, ahol az erős ipari örökség és a rendszerváltás utáni kedvező földrajzi pozíció együttese az innovatív szerkezetváltás felé hat (lásd Győr esetét), de nem kielégítő a drasztikus ipari válságon átmenő vagy versenyképességüket fokozatosan, lépésenként elvesztő városi térségekben (Miskolc és Pécs példája). Valójában mind a helyi és regionális gazdaság megerősítésére, mind az újraiparosításra vagy más válságkezelési utakra törekvő stratégiák a közés magánszféra több szereplőn nyugvó fejlesztési együttmüködését igénylik; a posztszocialista periféria kisebb nagyvárosaiban pedig jelenleg az erőforrás-koncentráció logikáján nyugvó térségi specializáció tűnik sikeresebb fejlesztési útnak. A következőkben tehát kísérletet teszek az innovációorientált fejlesztési együttmüködés egy lehetséges intézményi felfogásának leírására, amely alkalmas lehet e cél elérésére. Ez a kérdés a területi innovációs rendszer és az innovációs folyamat irányításáról, összefogásáról szól (3. ábra).

Az innováció vezérlése a gazdaságszerkezetet mint térségen belül értelmezett kapcsolatrendszert átható, alakító erő segítségével megy végbe. Ezt a szerepet ideális esetben a gazdasági és kormányzati célokat összefogó városi rezsimek tölthetnék be, fejlesztési impulzusokkal, az iparági klaszterekkel mint operatív eszközökkel befolyásolva a területi innovációs folyamat irányait.

Ebben a tanulmányban nem foglalkozom részletesen a klaszterorientált fejlesztéspolitika kérdéseivel; ezeket mások rendkívüli részletességben és mélységben tárgyalták (Asheim, Cooke, Martin 2006; Lengyel 2010; Lengyel, Rechnitzer 2004 stb.); csak egy, a vizsgált téma kapcsán releváns szempontot érintek. Van den Berg, Braun és van Winden (2001) hívta fel a figyelmet a klaszteréletciklusok és az agglomerációs folyamatok összefüggéseire, ${ }^{3}$ kiemelve hogy a kifejlett, érett klaszterek számottevő előnyökkel rendelkeznek, többek között a skálahatásoknak köszönhetően (a marshallihoz hasonló) agglomerációs externáliákat élvez-

3. ábra: A vezérlés mint a területi innovációs rendszer hiányzó eleme

Control as the missing function of the regional innovation system

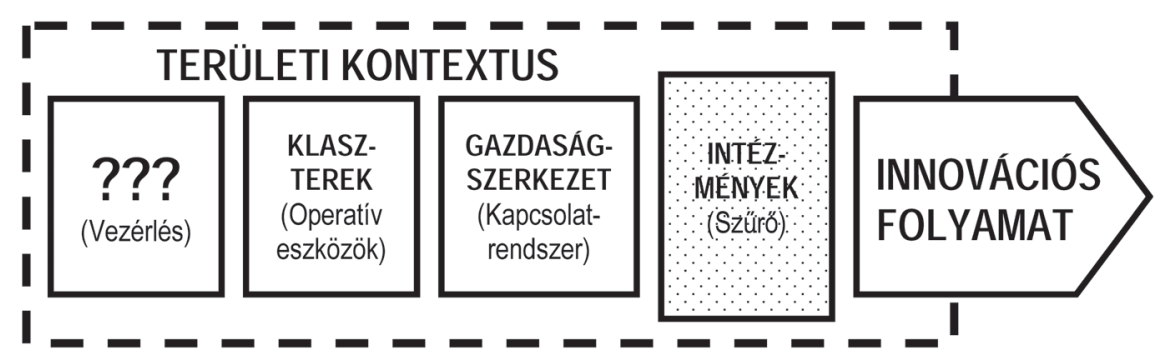


nek, életkoruk pedig megkönnyíti a klaszter teljesítménye szempontjából kulcsfontosságú, hosszú távú együttműködésen nyugvó stratégiai interakciók kibontakozását. A klaszterek sikeressége belső önszervező képességükön, a szereplők részvételén és a tanulási folyamatok sikerességén is múlik, tehát a fejlődési folyamatban jelentős szerepet játszik az erős, hatékony intézményi környezet. Ezek a megállapítások a klaszterfejlődés korai fázisában járó vagy gyenge kritikus tömegekkel rendelkező városi térségekben az inkubáció, valamint a fejlesztési folyamatot átfogó és koordináló, a várostérségi gazdasághoz kötődő szervezetek szükségességét vetik fel az innovációs folyamat irányítása érdekében.

Az innovációs folyamat eredményei a tágan értelmezett, helyi, országos és transznacionális léptékekben megjelenő intézmények együttes befolyásával, egyfajta szürőn keresztül válnak valós termékké. A legfontosabb szűrőhatás maga a helyi társadalom cselekvőképessége, önszervező ereje, amely a társadalmi tőke mennyiségi és minőségi adottságaitól függő tényező. ${ }^{4}$ Ha a szűrő „eltömődött”, vajmi csekély innováció szabadul fel a rendszerből: a máshol kiválóan bevált fejlesztési modellek nem kellően körültekintő átplántálása számos esetben eredményezett más intézményi környezetben negyedsikereket, fejlesztési kudarcokat.

Az imént leírt modell is jelzi, hogy az innovációs rendszerek általános felfogása gyakran túlságosan idealizált képet nyújt. Kisméretü, a gazdasági és kormányzati szereplők gyengeségével küzdő közép-európai városi térségekben ugyanis mérsékeltek az USA és Nyugat-Európa tereire kidolgozott, a köz- és versenyszféra hatékony együttműködését feltételező városi rezsim koncepciójának megvalósítási esélyei, az innovációs rendszerből éppen az irányító, összefogó erő hiányzik: a rendszer fej nélküli torzó. Logikus következtetés, hogy ezt a hiányzó elemet valamilyen formában pótolni kell. Sem az amerikaihoz vagy nyugat-európai magtérségekhez mérhető városi agglomerációk, sem erős üzleti elitek nem működnek a kisebb nagyvárosokra és középvárosokra alapozott térben, de a fejlődés feltételeit befolyásoló intézményrendszer dinamikus értelmezése, tanulási képességének kiaknázása (vö. Lengyel, Bajmócy 2013) reményt ad arra, hogy a fejlesztő együttműködés hatékony intézményei ha nem is léteznek, de legalább megteremthetók.

További kérdés az irányítás szereplőinek mibenléte. Nyilvánvaló, hogy meghatározó hazai tulajdonú „nemzeti bajnok” vállalatok, gazdasági érdekcsoportok hiányában másféle, kisebb egységek összekapcsolásán nyugvó szervezeti logikát érdemes érvényesíteni. Álláspontom szerint a gazdasági érdekek hatékony képviseletére, egyben közösségi kontrolljára a kereskedelmi és iparkamarák, valamint a fejlesztéspolitikai intézményrendszer szereplőinek együttmüködése tehető alkalmassá, mivel ezek a szervezetek rendelkeznek a fejlesztési irányok kijelöléséhez szükséges szakértelemmel és közösségi legitimációval. Az együttműködés két fő logika mentén valósulhat meg. Vagy informális kapcsolatokon alapuló fejlesztési koalíciók, vagy pedig a Közép-Európában viszonylag erős hagyományokkal rendelkező, a neoliberális modell alternatívájaként értelmezhető, oszt- 
rák és délnémet neokorporativista felfogáshoz közel álló formalizált együttmüködési rendszerek kialakítása tűnik célszerűnek. A kamarák a diffúz, kis szereplők sokaságán alapuló üzleti környezetben képesek, tagságuk révén pedig alkalmasak és felhatalmazottak a fejlesztéspolitika irányainak kijelölésére. Mint Maenning és Ölschlager (2011) Németország példáján hangsúlyozza, a helyi elitben elfoglalt kulcsszerepük révén kiválóan alkalmasak a kapcsolati és társadalmi tőke (újra-)termelésére.

Bár Magyarországon a kötelező kamarai tagság eltörlése csökkentette legitimitásukat, és ezt a 2012-ben kötelezővé tett kamarai regisztrációs kötelesség korántsem állította vissza (a fölöttük gyakorolt központi kontroll erősödése éppen térségi szerepük leértékelődésével fenyeget), mégis a gazdasági érdekképviselet és az üzleti promóció meghatározó szereplői, elsősorban a hazai tőke érdekeit képviselve, de a multinacionális vállalatok szükségleteit is figyelembe véve a területi gazdasági érdekek legfontosabb artikulálói maradtak (Póla 2006, 2009). A kamarák olyan feladatokat látnak el, amelyeket a városi és megyei önkormányzatok jelenleg nem képviselnek. Az érdekképviselet másik tartópillérében a fejlesztéspolitika kiépült intézményei (pl. regionális innovációs ügynökségek) láthatnak el a térségi érdekeket és a nemzeti fejlesztési irányokat szintetizáló szerepkört. Az EU strukturális alapjai forrásainak fogadására létrehozott szervezetek a közösségi (területi) tervezésben, a fejlesztéspolitika menedzselésében egyaránt értékes kapacitásokkal, tudással rendelkeznek.

\section{Összefoglalás}

A globális gazdaság múködési logikájában a nagyvárosok térszervező szerepének nagymértékű felértékelődése megy végbe, a koncentrációs folyamatok pedig új nyertesekre és vesztesekre osztják a teret. Míg a globális városhálózat kitüntetett csomópontjaiban elhelyezkedő metropolisztérségek az első, addig a kisebb nagyvárosok a második csoportba tartoznak. Közép-Európában a periferikus térszerkezeti pozíció, a gazdasági lemaradás és a kritikus tömegek hiánya miatt az ideális fejlódési út csak a fóvárosi agglomerációk és néhány kivételezett centrum számára követhető’; az uralkodó fejlesztési irányokban prioritást élvező fejlett üzleti szolgáltatások erős agglomerálódásuk miatt nem eredményeznek területi kiegyenlíto”dést. A kisebb nagyvárosok esetében vagy a termelési-szolgáltatási rendszerek hierarchiáiba való, általános versenystratégiákon alapuló betagozódás, vagy az egyedi versenyelőnyökre és belső erőforrásokra alkalmazott növekedési stratégia enyhítheti a kedvezőtlen kiinduló helyzetet.

Megfigyelhetö, hogy a versenyképességi, befektetésvonzási tényezók körében a kívülról meghatározott feltételek mellett növekvőben van a térségspecifikus, térben differenciált elemek aránya és azok együttes komplexitása, ami a várostérségek koordinált fejlesztő szerepét igényli. Az intézményfejlődés, a gazdaság hálózatos szerveződése 
és az innovációs rendszer kiépülése számottevő eltéréseket mutatott a vizsgált városi térségek között; sőt, a tőkeellátottság mellett ezek a tényezők rendelkeztek a legnagyobb különbségekkel. A versenyképesség magasabb szintjein, ahol a puszta költségelőnyökön túlmutató tényezők kerülnek előtérbe, ezek a korábban „puha” adottságok meghatározó jelentőségűvé válnak. Fejlesztési együttműködés még nem figyelhető meg a nyugati mintájú városi rezsimeknek megfeleltethető formában, de az üzleti szféra alulról építkező szerveződésében - és olykor a városi önkormányzatokkal, közintézményekkel kialakított kapcsolataiban - már megtaláljuk a szorosabb kapcsolatrendszerek alapvonalait. A csekély városi méret és a folyamatos intézményi deficit ellenére mind a fejlesztésre alkalmas kapacitások, mind a működő kapcsolatok nyomai feltárhatók a magyar kisebb nagyvárosokban.

A közép-európai kisebb nagyvárosok számára az univerzális fejlesztési receptek helyett a belső (endogén) eróforrásokra alapozott, a városi térségen belüli innovációs rendszer fejlődését elősegito" és az emberi erőforrások, a társadalmi tőke fejlesztésére irányuló cselekvés biztat kedvező eredményekkel, amely képes egyensúlyt teremteni az agglomerációs előnyöket hatékonyan kihasználó specializáció és a rugalmas alkalmazkodást elősegítő diverzifikáció között. Az innovációs rendszer operatív eszközeiként az iparági klaszterek jönnek számításba, az innovációs folyamat irányait kijelölő rendszerként pedig a városi rezsimeket helyettesitoo, a közép-európai körülményekre adaptált együttmüködési formák kínálnak kedvező intézményi keretet. Az együttműködés kialakult intézményei mind tartalmukban, mind formájukban környezetük termékei lesznek: mozaikosabb alapon szerveződöttek és nyugati társaiknál talán gyengébbek, de az innovatív fejlesztéspolitika számára legalább annyira értékesek.

\section{Köszönetnyilvánítás}

A tanulmány a TÁMOP-4.2.2.A-11/1/KONV-2012-0010 projekt (A győri járműipari körzet mint a térségi fejlesztés új iránya és eszköze) támogatásával készült. A szerző köszönettel tartozik a tanulmányához érkezett építő kritikákért; a fennmaradó hibákért őt terheli a felelősség.

\section{Jegyzetek}

1 Ebben a tanulmányban az agglomerálódási folyamatokkal és az agglomerációkkal mint kompakt városi térségekkel foglalkozom. Az agglomeráció kifejezését tehát a központi város és környéke együtteseként, funkcionális városi térség értelemben használom: a vizsgált területi léptéken a szuburbánus, periurbánus terek gazdasági funkciói önmagukban nem értelmezhetők.

2 Lásd Saxenian (1996) meghatározó tanulmánykötetét két emblematikus növekedési térségről, a Szilícium-völgyről és a Route 128-ról. 
3 A kérdésnek a Regional Studies folyóirat 2011-ben különszámot szentelt; lásd Boschma és Fornahl (2011) összefoglalóját és más írásokat.

4 Az immateriális tőkefajtákról és a területi tőkéről lásd Tóth (2010) rendszerező tanulmányát.

\section{Irodalom}

Ache, P. (2000): Cities in old industrial regions between local innovative milieu and urban governance - Reflections on city region governance. European Planning Studies, 6. 693-709.

Asheim, B., Cooke, P. Martin, R. (2006): The rise of the cluster concept in regional analysis and policy: A critical assessment. In: Asheim, B., Cooke, P., Martin, R. (eds.): Clusters and regional development. Routledge, London, New York, 1-29.

Audretsch, D. B. (1998): Agglomeration and the location of innovative activity. Oxford Review of Economic Policy, 2., 18-29.

Bajmócy Z. (2006): Egyetemi üzleti inkubáció lehetőségei elmaradott térségekben. Tér és Társadalom, 3., 31-47.

Barta Gy. (témavezető) (2002): A területfejlesztés gazdaságot támogató eszközeinek, megoldásainak hatékonysága. MTA Regionális Kutatások Központja Közép- és Észak-Magyarországi Tudományos Intézet, Budapesti Osztály, Budapest

Barta, Gy., Csizmadia, Z., Deák, Cs., Dőry, T., Kiss, A., Lengyel, B. (2011): R\&D cooperation between universities and enterprises. Centre for Regional Studies of Hungarian Academy of Sciences, Pécs (Discussion Papers; 84.)

Benko, G. (1992): Technológiai parkok és technopoliszok földrajza. MTA Regionális Kutatások Központja, Budapest

Benneworth, P. (2004): In what sense 'regional development'?: Entrepreneurship, underdevelopment and strong tradition in the periphery. Entrepreneurship \& Regional Development, 5., 439-458.

Benneworth, P., Charles, D. (2005): University spin-off policies and economic development in less successful regions: Learning from two decades of policy practice. European Planning Studies, 4., 537-557.

van den Berg, L., Braun, E., van Winden, W. (2001): Growth clusters in European cities: An integral approach. Urban Studies, 1., 185-205.

Boschma, R., Fornahl, D. (2011): Cluster evolution and a roadmap for future research. Regional Studies, 10., 1295-1298.

Brouwer, E., Budil-Nadvornikova, H., Kleinknecht, A. (1999): Are urban agglomerations a better breeding place for product innovation? An analysis of new product announcements. Regional Studies, 6., 541-549.

Caniëls, M. C. J., Romijn, H. A. (2006): Localised knowledge spillovers: The key to innovativeness in industrial clusters? In: Cooke, P., Piccaluga, A. (eds.): Regional development in the knowledge economy. Routledge, London, New York, 22-42.

Csizmadia Z., Grosz A. (2011): Innováció és együttmúködés: A kapcsolathálózatok innovációra gyakorolt hatása. MTA Regionális Kutatások Központja, Pécs, Győr

Csomós Gy. (2011): A közép-európai régió nagyvárosainak gazdaságirányító szerepe. Tér és Társadalom, 3., 129-140.

Derudder, B., Taylor, P. J., Witlox, F., Catalano, G. (2003): Hierarchical tendencies and regional patterns in the world city network: A global urban analysis of 234 cities. Regional Studies, 9., 875-886.

Egyed, I. (2009): A fél évszázados múltú francia területfejlesztés (aménagement du territoire) és egy középváros bemutatása a változó paradigmák fókuszában. Tér és Társadalom, 1., 167-180.

Erdős K., Varga A. (2010): Az egyetemi vállalkozó - Legenda vagy valóság az európai regionális fejlődés elősegítésére? Közgazdasági Szemle, 5., 457-472.

Erdősi F. (2003a): Globalizáció és a világvárosok által uralt tér. Tér és Társadalom, 3., 1-27. 
Erdősi F. (2003b): Globalizáció és a világvárosok által uralt tér II. Tér és Társadalom, 4., 1-16.

ESPON (2010): First ESPON 2013 synthesis report. New evidence on smart, sustainable and inclusive territories. The ESPON 2013 Programme, Luxembourg

Faragó L. (2006): A városokra alapozott területpolitika koncepcionális megalapozása. Tér és Társadalom, 2., 83-102.

Faragó L. (2010): Területi koncentráció és a jelentőségüket vesztő perifériák. In: Barta Gy., Beluszky P., Földi Zs., Kovács K. (szerk.): A területi kutatások csomópontjai. Magyar Tudományos Akadémia Regionális Kutatások Központja, Pécs, 432-453.

Gál Z. (2006): Innovációs potenciál. In: Hajdú Z. (szerk.): Dél-Dunántúl. Magyar Tudományos Akadémia Regionális Kutatások Központja, Dialóg Campus Kiadó, Pécs, Budapest, 357-379. (A Kárpát-medence régiói; 3.)

Gál Z. (2010): Pénzügyi piacok a globális térben. A válság szabdalta pénzügyi tér. Akadémiai Kiadó, Budapest

Gordon, I. R., McCann, P. (2000): Industrial clusters: Complexes, agglomeration and/or social networks. Urban Studies, 3., 513-532.

Hardi, T. (2010): Cities, regions and transborder mobility along and across the border. Centre for Regional Studies of Hungarian Academy of Sciences, Pécs (Discussion Papers; 82.)

Harrison, B. (1992): Industrial districts: Old wine in new bottles? Regional Studies, 5., 469-483.

Hegedüs J. (2008): A nagyvárosi kormányzatok és az önkormányzati rendszer. Tér és Társadalom, 1., 59-75.

Horeczki R. (2011): A Dél-Dunántúl kisvárosai, a „gyenge mágnesek”. In: Páger B. (szerk.): Évkönyv 2011. Pécsi Tudományegyetem Közgazdaság-Tudományi Kara, Regionális Politika és Gazdaságtan Doktori Iskola, Pécs, 57-68.

Hrubi L. (2009): Tudás és újraiparosítás a dél-dunántúli régióban. In: Fodor I. (szerk.): A régiók újraiparositása. A Dél-Dunántúl esélyei. MTA Regionális Kutatások Központja, Pécs, 61-68.

Koós B. (2010): A gazdasági tevékenységek agglomerálódása egy vállalatdemográfiai modell tükrében. Tér és Társadalom, 1., 51-64.

Krugman, P. (1991): Increasing returns and economic geography. Journal of Political Economy, 3., 183-199.

Lengyel B., Szanyi M. (2011): Agglomerációs előnyök és regionális növekedés felzárkózó régiókban - A magyar átmenet esete. Közgazdasági Szemle, 10., 858-876.

Lengyel B., Bajmócy Z. (2013): Regionális és helyi gazdaságfejlesztés az evolúciós gazdaságföldrajz szemszögéből. Tér és Társadalom, 1., 5-29.

Lengyel I. (2010): Regionális gazdaságfejlesztés. Versenyképesség, klaszterek és alulról szerveződo” stratégiák. Akadémiai Kiadó, Budapest

Lengyel I., Mozsár F. (2002): A külső gazdasági hatások (externáliák) térbelisége. Tér és Társadalom, 2., $1-20$.

Lengyel I., Rechnitzer J. (2004): Regionális gazdaságtan. Dialóg Campus Kiadó, Budapest, Pécs

Lux G. (2009): Az ipar hagyományos terei: A régi ipari térségek. Tér és Társadalom, 4., 45-60.

Maenning, W., Ölschläger, M. (2011): Innovative milieu and regional competitiveness: The role of associations and chambers of commerce and industry in Germany. Regional Studies, 4., 441-452.

Markusen, A. (1996): Sticky places in slippery space: A typology of industrial districts. Economic Geography, 3., 293-313.

Nagy E. (2012): Verseny vagy kiegyenlítés? Az európai várospolitika neoliberális fordulata és a helyi tervezési-fejlesztési gyakorlatok „projektesítése”. In: Pál V. (szerk.): A társadalomföldrajz lokális és globális kérdései. SZTE TTIK Gazdaság- és Társadalomföldrajz Tanszék, Szeged, 54-67.

Paci, R., Usai, S. (1999): Externalities, knowledge spillovers and the spatial distribution of innovation. GeoJournal, 4., 381-390.

Pálné Kovács I. (2010): Városi terek kormányzása és a városi rezsimek: Egy induló kutatás margójára. Tér és Társadalom, 4., 3-27.

Pálné Kovács, I. (2011): Local governance in Hungary: The balance of the last 20 years. Centre for Regional Studies of Hungarian Academy of Sciences, Pécs (Discussion Papers; 83.) 
Pálné Kovács I. (2012): Nagyvárosi fejlesztési koalíciók. In: Somlyódyné Pfeil E. (szerk.): Az agglomerációk intézményesitésének sajátos kérdései. Három magyar nagyvárosi térség az átalakuló térben. Publikon Kiadó, Pécs, 135-151.

van der Panne, G. (2004): Agglomeration externalities: Marshall versus Jacobs. Journal of Evolutionary Economics, 5., 593-604.

Póla P. (2006): Gazdasági kamarák a globalizációban. Tér és Társadalom, 3., 19-30.

Póla P. (2009): Az újraiparosítás intézményi feltételei. In: Fodor I. (szerk.): A régiók újraiparositása. A Dél-Dunántúl esélyei. MTA Regionális Kutatások Központja, Pécs, 69-78.

Rechnitzer J. (2005): A magyar városhálózat innovációs potenciálja. In: Grosz A., Rechnitzer J. (szerk.): Régiók és nagyvárosok innovációs potenciálja Magyarországon. Magyar Tudományos Akadémia Regionális Kutatások Központja, Pécs, Győr, 147-181.

Ricz J. (2007): Az agglomerálódás klasszikus és új logikája. Külgazdaság, 7-8., 83-102.

Sassen, S. (1991): The global city. New York, London, Tokyo. Sage Publications, London

Sassen, S. (2006): Cities in a world economy. Sage Publications, London

Saxenian, A. (1996): Regional advantage: Culture and competition in Silicon Valley and Route 128. Harvard University Press, Cambridge, London

Sollé-Ollé, A., Viladecans-Marsal, E. (2004): Central cities as engines of metropolitan area growth. Journal of Regional Science, 2., 321-350.

Somlyódyné Pfeil E. (2008): A városi térségek a közigazgatási struktúra és a „governance” keresztmetszetében. Tér és Társadalom, 1., 27-43.

Somlyódyné Pfeil E. (2011): Az agglomerációk jelentőségének változása az államszervezés és a városi kormányzás szempontjából. Tér és Társadalom, 3., 27-59.

Somlyódyné Pfeil E. (2012): Az együttműködésnek mint erőforrásnak a jelenléte három nagyvárosi térségünkben. In: Somlyódyné Pfeil E. (szerk.): Az agglomerációk intézményesitésének sajátos kérdései. Három magyar nagyvárosi térség az átalakuló térben. Publikon Kiadó, Pécs, 201-221.

Storper, M. (1992): The limits to globalization: Technology districts and international trade. Economic Geography, 1., 60-93.

Sucháček, J. (2010): On the emergence of minor cities. In: Sucháček, J., Petersen, J. J. (eds.): Developments in minor cities: Institutions matter. VŠB, Technical University of Ostrava, Ostrava, 13-28.

Suvák A. (2011): Környezeti fenntarthatóság mint az életminőségi stratégia része Európa középvárosaiban. In: Páger B. (szerk.): Évkönyv 2011. Pécsi Tudományegyetem Közgazdaság-tudományi Kara, Regionális Politika és Gazdaságtan Doktori Iskola, Pécs, 233-244.

Suvák A. (2012): Az egy térségben való gondolkodás vizsgálata a tervezési gyakorlat és a központi városhoz kötődés néhány szempontján keresztül Magyarország három agglomerációjában. In: Somlyódyné Pfeil E. (szerk.): Az agglomerációk intézményesitésének sajátos kérdései. Három magyar nagyvárosi térség az átalakuló térben. Publikon Kiadó, Pécs, 181-199.

Sýkora, L., Mulíček, O. (2009): The micro-regional nature of functional urban areas (FUAs): Lessons from the analysis of the Czech urban and regional system. Urban Research and Practice, 3., 287-307.

Szalavetz, A. (2003): European policy lessons in the process of regional transformation in Hungary. In: Steiner, M. (ed.): From old industries to new regions. Policies for structural transformations in accession countries. Leykam Buchverlagsgesselschaft, Graz, 179-195.

Szerb L. (2009): Tradicionális és új iparágak fejlesztési lehetőségei Magyarországon és a Dél-Dunántúlon. In: Fodor I. (szerk.): A régiók újraiparositása. A Dél-Dunántúl esélyei. MTA Regionális Kutatások Központja, Pécs, 45-60.

Taylor, P. J., Walker, D. R. F. (2001): World cities: A first multivariate analysis of their service complexes. Urban Studies, 1., 23-47.

Tóth B. I. (2010): Az immateriális és a területi tőke összefüggései. Tér és Társadalom, 1., 65-81.

Tóth B. I. (2012): Regionális rugalmasság - rugalmas régiók. Tér és Társadalom, 2., 3-21.

Viladecans-Marsal, E. (2002): The growth of cities: Does agglomeration matter? Institut d'Economia de Barcelona, Centre de Recerca en Federalisme Fiscal I Economia Regional, Barcelona

Voith, R. (1998): Do suburbs need cities? Journal of Regional Science, 3., 445-464. 